\title{
Nonuniform stress state of a hoisting shaft lining as a result of disturbance of the ground freezing technology
}

\author{
Oleksii Tiutkin ${ }^{1, *}$, Vitalii Miroshnyk ${ }^{1}$, Anatolii Radkevych ${ }^{1}$, and Ahmad Alkhdour ${ }^{2}$ \\ ${ }^{1}$ Dnipro National University of Railway Transport named after Academician V. Lazaryan, 49010, \\ Dnipro, Lazaryan Str., 2, Ukraine \\ ${ }^{2}$ Al-Balqa`Applied University, 19117, Al-Salt, Jordan
}

\begin{abstract}
The paper deal with the defining stress state of a hoisting shaft lining, lying in the sandy loam, when performing and disturbing the ground freezing technology. The relevance of the performed research lies in the fact that at nonuniform freezing or defrosting, nonuniform stress state is formed, which causes a significant over-stresses of the lining. To research the nonuniform stress state, a spatial finite element model of a hoisting shaft was developed, in which the case of nonuniform ground freezing was simulated. The calculation by the finite-element technique was carried out on the basis of the computational professional complex Structure CAD for Windows. In the course of the analysis, the values of stress state for linings made of reinforced-concrete blocks, B30 concrete, gray and modified castiron tubbings. A comparison of the components of stress state for sandy loam at a temperature of $-2{ }^{\circ} \mathrm{C}$ (freezing), nonuniform freezing and at a temperature of $+8^{\circ} \mathrm{C}$ (defrosting) was carried out. It was found that for the proposed geotechnical conditions in the form of soft, water-saturated sandy loam, it is recommended to use a lining made of gray and modified castiron tubbings.
\end{abstract}

\section{Introduction}

In the construction of underground facilities in a closed way, for example, deep-laid lines, the opening of the widest front of operations plays an important role at the first stage of construction. Such a strategic move requires the creation of an above-ground mine complex, a hoisting shaft and a complex of workings around the shaft. Thereafter, one can consider that spread of work is opened, which includes the development of the rock, its loading and moving-out, transportation of materials for the construction, installation and finishing operations, as well as additional ones to maintain the normal operation of workers (ventilation, drainage, lighting, etc.). The speed in the starting the spread of work and, accordingly, the time of construction of the objects in a closed way are related to the speed of the hoisting shaft construction, as well as with its further normal operation, which allows performing the continuous plan operation at the bottom level [1].

\footnotetext{
${ }^{*}$ Corresponding author: alexeytutkin@gmail.com
} 
However, the construction of vertical workings is often face with the complexities associated with the engineering-geological situation of the construction. Although hoisting shafts for undergrounds have a small depth $(30-50 \mathrm{~m})$, they cross the layered massif, which is often composed of soft grounds such as sands, loams and sandy loams. The complexity of the engineering-geological situation is compounded by the presence of one or several ground water levels in such massifs. This, in turn, requires the use of special methods of operations that let normal work at the development of grounds and installation of the lining. The main of these operation methods, which cuts off underground water from the working area and strengthens the soft grounds of the surrounding massif, is freezing [2-4].

This complex, labor-consuming and expensive method of maintaining the working in a stable state has a significant advantage, which other ones do not have: it is guaranteed to retain underground water outside of ice-ground blocking [2, 4]. In the active stage of freezing, when a stable negative temperature is maintained in blocking, stress state of the multilayer "surrounding massif ground-frozen ground-hoisting shaft lining" system remains stable, which is confirmed by the conducted research $[2,5,6]$. In the paper [6], the authors proposed to control stress state of the lining with the selection of effective parameters (for example, thickness), depending on the parameters of the special method of freezing.

However, as discussed in the paper [2], there are cases in which freezing is carried out with disturbance of the technology, which leads to the emergence of ice-ground blocking of a clearly nonuniform shape with a significant change in thickness around the working. This leads to the formation of nonuniform stress state, which becomes a cause of failures during the construction of a hoisting shaft. A similar situation may occur both in the stage of passive freezing and defrosting, which has already leads to over-stresses of the hoisting shaft lining and potential nonuniform deformations.

Thus, it is necessary to conduct the research of a hoisting shaft with the consideration of differential defrosting in order to determine the effect of the nonuniform layer of the iceground blocking on the formation of stress state of a hoisting shaft and the surrounding massif ground at its freezing or defrosting.

\section{Methods}

Undoubtedly, the research of a hoisting shaft should be carried out only with the use of a spatial model, since forming stress state applies to all its components. Such a model, based on the finite-element technique, had already been created earlier and widely tested in a number of studies of hoisting shafts [6-8]. It is this indicated model that allowed to study stress state of the shaft in the process of freezing and offer stress state control basics of the lining with the selection of effective parameters [6]. The following research also applies this model, which is based on volumetric finite elements and simulates a hoisting shaft with a depth of 40 meters and an internal diameter of $5.1 \mathrm{~m}$ [6] (Fig. 1).

After creating the spatial model, it was given with deformation characteristics (modulus of elasticity-deformation, Poisson ratio), at this they were set separately for grounds, iceground blocking and material of the lining. The task of deformation characteristics in a hoisting shaft model required that the ice-ground blocking was simulated only on the left side of it, that is, it simulates the case in which half of the lining was already in the defrosted ground (Fig. 2).

Three types of linings were investigated: 1) reinforced-concrete blocks; 2) gray castiron tubbings; 3 ) modified gray cast-iron tubbings are in the sandy loam at a temperature of $-2{ }^{\circ} \mathrm{C}$ (frozen) and $+8{ }^{\circ} \mathrm{C}$ (defrosted). The deformation characteristics of the model are as follows: 1) reinforced-concrete blocks, B30 concrete - reduced elasticity modulus is $E=2.03 \cdot 10^{4} \mathrm{MPa}$, Poisson ratio is $\mu=0.3$, specific weight is $\gamma=24.5 \mathrm{kN} / \mathrm{m}^{3}$; 2) gray cast-iron 
tubbings - elasticity modulus is $E=1.95 \cdot 10^{5} \mathrm{MPa}$, Poisson ratio is $\mu=0.3$, specific weight is $\gamma=72 \mathrm{kN} / \mathrm{m}^{3}$; 3) modified gray cast-iron tubbings - elasticity modulus is $E=2.93 \cdot 10^{5} \mathrm{MPa}$, Poisson ratio is $\mu=0.3$, specific weight is $\gamma=48 \mathrm{kN} / \mathrm{m}^{3}$; sandy loam at a temperature $t=-2{ }^{\circ} \mathrm{C}$, elasticity modulus is $E=21 \mathrm{MPa}$, Poisson ratio is $\mu=0.3$, specific weight is $\gamma=20 \mathrm{kN} / \mathrm{m}^{3}$; sandy loam at a temperature $t=+8{ }^{\circ} \mathrm{C}$, elasticity modulus is $E=15 \mathrm{MPa}$, Poisson ratio is $\mu=0.3$, specific weight is $\gamma=20 \mathrm{kN} / \mathrm{m}^{3}$.

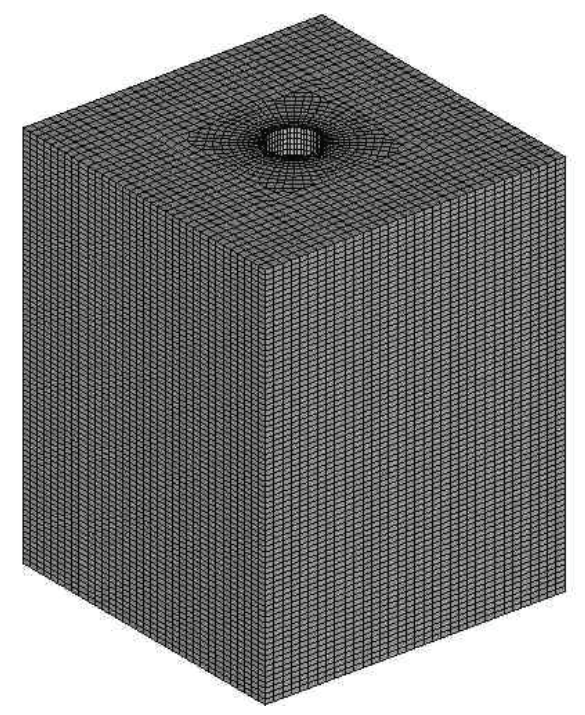

Fig. 1. The finite element model of a hoisting shaft [6].

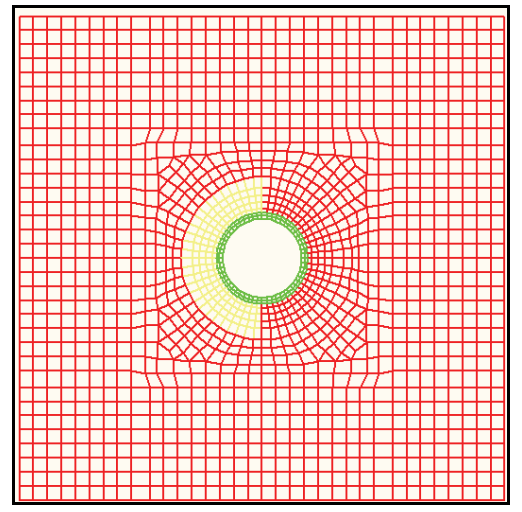

Fig. 2. Scheme of deformation characteristics of a hoisting shaft model in plan.

After defining the model with deformation characteristics, the boundary conditions were assigned to it and it was loaded with its own weight. The calculation by the finite-element technique was carried out on the basis of the computational professional complex Structure CAD for Windows (license number F755B84 (KMBKB RA 4810)) [9].

\section{Results and discussion}

Figure 3 demonstrates isolines and isofields of the model stresses under calculation, correspond to the longitudinal sections of the hoisting shaft that have the form of a semicircle and are presented in full faced from the inside part to the reader. 

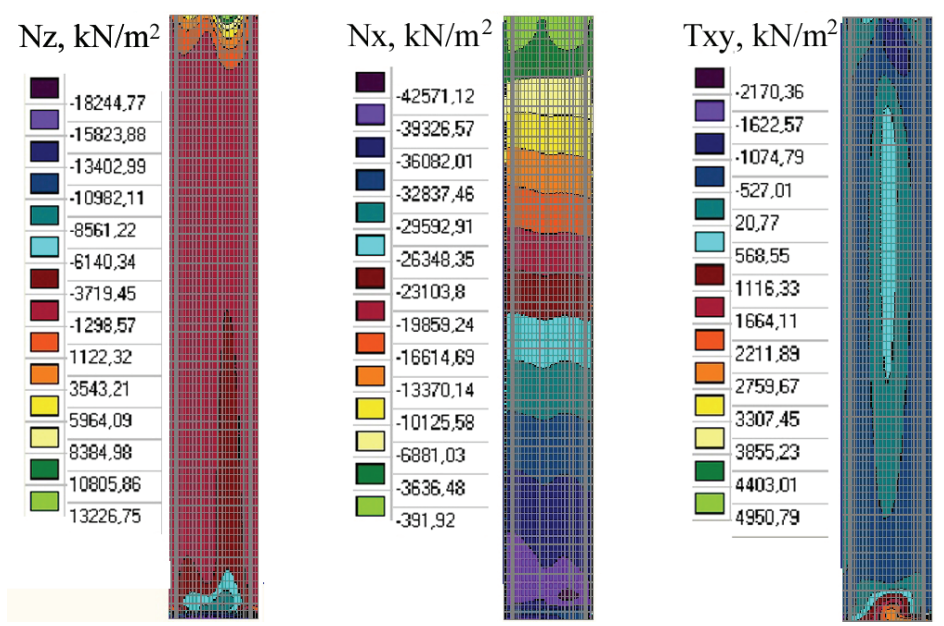

Reinforced-concrete blocks, B30 concrete
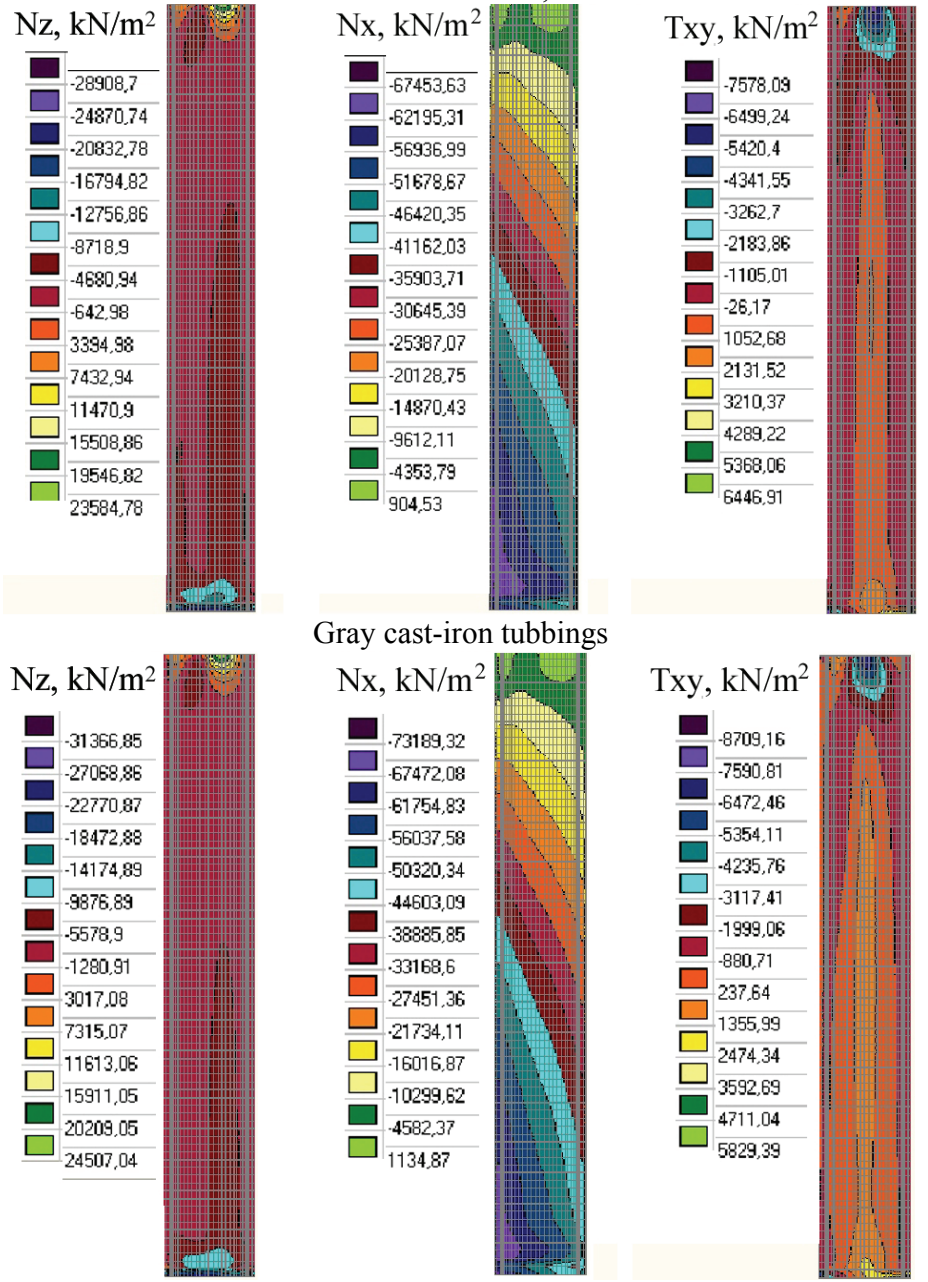

Gray cast-iron tubbings
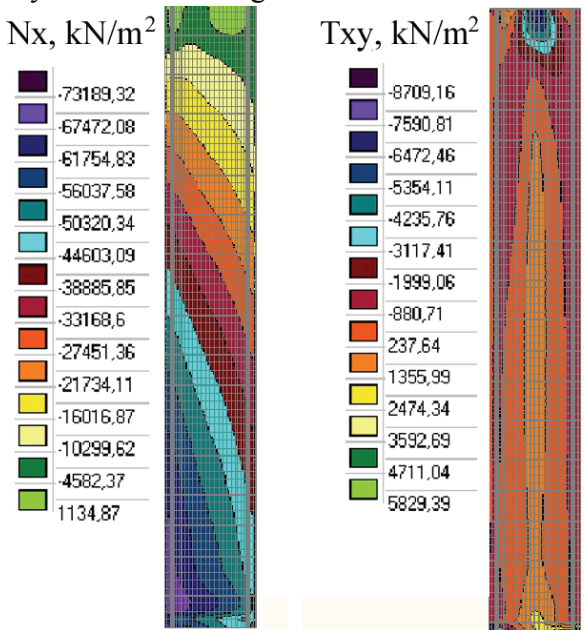

Gray and modified

Fig. 3. Isolines and isofields of the stresses in a hoisting cast-iron tubbings shaft lining at nonuniform freezing. 
At the qualitative analysis of the stress state results, characteristic patterns of stresses in the shaft mouth and in the base of a hoisting shaft can be noted. Compared to the isofields of horizontal stresses in the linings at uniform freezing [6, 8], the maxima of the nonuniform freezing isofields are strongly displaced towards the defrosted grounds and are strongly elongated, at this the shorter part of the isofield is always located at the side of the ground with a greater elasticity modulus, that is, the frozen part. In the lowest isofield, which has the wrong shape, the greatest normal horizontal stresses are observed.

Above Figure 3 five layers of isofields are shown representing the sectors of the ring arc and at uniform freezing are bounded by the upper edge of the hoisting shaft section, while in the case of nonuniform freezing, they have a distorted shape with displacement of the stresses patterns towards the ground with a lower elasticity modulus.

For greater clarity, the quantitative analysis of the changing stress state in the hoisting shaft linings we will present in the form of Table 1.

It is also important to observe that the slope of isofields at ground freezing with linings made of cast-iron tubbings and tubbings made of modified gray cast-iron is approximately $45^{\circ}$, while the isofields slope at ground freezing in the linings made of reinforced-concrete blocks is $10^{\circ}$, indicating that the slope angle of isofields of vertical stresses depends on the elasticity modulus of the hoisting shaft lining. It should be reminded that at uniform freezing the isolines are perpendicular to the axis of a hoisting shaft.

Table 1. Stress state of the hoisting shaft linings at nonuniform freezing.

\begin{tabular}{|c|c|c|c|c|c|c|c|c|c|}
\hline $\begin{array}{c}\text { Components } \\
\text { of } \\
\text { stress state, } \\
\text { MPa }\end{array}$ & \multicolumn{3}{|c|}{$\begin{array}{c}\text { Sandy loam } \\
\text { at a temperature } \\
t=-2{ }^{\circ} \mathrm{C}\end{array}$} & \multicolumn{3}{c|}{$\begin{array}{c}\text { Nonuniform } \\
\text { freezing }\end{array}$} & \multicolumn{3}{c|}{$\begin{array}{c}\text { Sandy loam } \\
\text { at a temperature } \\
t=+8{ }^{\circ} \mathrm{C}\end{array}$} \\
\cline { 2 - 10 } & B30 & GC & MGC & B30 & GC & MGC & B30 & GC & MGC \\
\hline $\begin{array}{c}\text { Normal } \\
\text { stresses } \\
\text { on a } \\
\text { horizontal } \\
\text { axis }\end{array}$ & -14.0 & -27.2 & -28.8 & -18.2 & -28.9 & -31.4 & -16.3 & -28.0 & -29.4 \\
\hline $\begin{array}{c}\text { Normal } \\
\text { stresses } \\
\text { on a vertical } \\
\text { axis }\end{array}$ & -32.8 & -63.5 & -65.8 & -42.6 & -67.5 & -73.2 & -39.7 & -65.0 & -70.1 \\
\hline $\begin{array}{c}\text { Shear } \\
\text { stresses } \\
\text { within } \\
\text { vertical } \\
\text { plane }\end{array}$ & -1.9 & -7.5 & -7.9 & -2.2 & -7.6 & -8.7 & -2.0 & -7.5 & -8.2 \\
\hline
\end{tabular}

Note. B30 - reinforced-concrete blocks, concrete B30, GC - gray cast-iron tubbings, MGC - gray and modified cast-iron tubbings.

\section{Conclusions}

After the comparative analysis of the obtained data, it can be said that values of normal stresses in the case of nonuniform freezing are greater than in the case of a normal operation state of the hoisting shaft lining after defrosting. Misalignment of stresses caused by the nonuniform of freezing and defrosting cycle leads to local fractures and increased cracking in the shaft lining of reinforced-concrete tubbings (the maximum value is 42.6 MPa), therefore, for the proposed geotechnical conditions in the form of soft watersaturated sandy loam, it is recommended to use the lining made of gray and modified cast- 
iron tubbings. However, it should be noted that for these linings, the maximum of normal stresses is observed in the state of nonuniform freezing, which should be taken into account when designing and calculating.

The data obtained in the course of the research of nonuniform stress state of the hoisting shaft lining due to disturbance of the ground freezing technology open the prospect for further research, which should take into account the spatial non-uniformity of defrosting. After the stage of passive freezing, defrosting occurs nonuniformly in height, which is the normal course of this special process. However, in its course, there is a nonuniform change of the deformation characteristics, which can lead to nonuniform stress state which has to be investigated.

\section{References}

1. Petrenko, V.I., Petrenko, V.D., Tyutkin, A.L. (2005). Sovremennyye tekhnologii stroitelstva metropolitenov v Ukraine. Dnepropetrovsk: Nauka i osvita

2. Dorman, Ya.A. (1981). Spetsialnyye sposoby rabot pri stroitelstve metropolitenov. Moskva: Transport

3. O.B. Andersland, B. Ladanyi, Frozen Ground Engineering (John Wiley \& Sons, 2003)

4. J.S. Harris, Ground freezing in practice (Amer Society of Civil Engineers, 1995)

5. E. Pimentel, G. Anagnostou, A. Sres, Underground Space - The 4th Dimension of Metropolises, 1 (2007)

6. Tiutkin, O., Petrenko, V., Petrosian, N., Miroshnyk, V., Alkhdour, A. (2018). Controlling stress state of a hoisting shaft frame in the context of specific freezing process, Mining of Mineral Deposits, 12 (4), 28-36

7. Borshchevskiy, S.V., Petrenko, V.D., Tyutkin, A.L., Antonov, E.B., Pleshko, M.S. (2006). Raschet krepi stvola metodom konechnykh elementov. Heotekhnichna mekhanika, 66, 89-96

8. Levit, V.V., Tyutkin, A.L., Borshchevskiy, S.V. (2007). Matematicheskoye modelirovaniye sistemy «stvol - gorizontalnaya vyrabotka» metodom konechnykh elementov, Heotekhnichna mekhanika, 73, 41-54

9. Perelmuter, A.V., Slivker, V.I. (2002). Raschetnyye modeli sooruzheniy $i$ vozmozhnost ikh analiza. Kyiv: Stal 